\title{
Essential fatty acid deficiency in patients with lesions of the gastrointestinal tract
}

\author{
SIMON WAPNICK ${ }^{1}$, DAPHNE A. NORDEN, AND DAWN J. VENTURAS \\ From the Department of Surgery and the Department of Biochemistry, University of Rhodesia, Salisbury, \\ Rhodesia
}

SUMMARY The relative amounts of unsaturated fatty acids in the serum lipids of 14 patients who have undergone small bowel resection have been investigated. These results are compared with those from control subjects and also from patients suffering from cancer of the oesophagus.

Both groups of patients showed patterns of unsaturated fatty acids suggesting essential fatty acid deficiency. In the resection patients there was no correlation between the extent of intestinal removal and the extent of the change in the unsaturated fatty acid pattern.

Previous studies of fatty acid patterns in the serum have suggested that deficiency of essential fatty acids may occur in man. Derangement of the ratio of certain unsaturated fatty acids in serum lipid has been observed in malnourished children by Hansen and Wiese (1954) and in serum phospholipid after extensive bowel resection (Collins, Sinclair, Royle, Coats, Maynard, and Leonard, 1971). Increases in $5,8,11$-eicosatrienoic acid (a fatty acid containing 20 carbon atoms and three double bonds) were accompanied by a decrease in linoleic and arachindonic acids.

Experimental production of essential fatty acid deficiency in rats results in a relative increase in oleic $(18: 1 \omega 9)$ and 5, 8, 11-eicosatrienoic $(20: 3 \omega 9)$ acids and a decrease in linoleic $(18: 2 \omega 6)$ and arachidonic $(20: 4 \omega 6)$ acids in various tissue lipids (Guarini and Johnson, 1970). Holman (1960) has suggested that the ratio of trienoic to tetraenoic acids in tissue lipids can therefore be used as an index of the development of essential fatty acid deficiency in rats, a ratio higher than 0.4 indicating deficiency. In this paper we report the relative amounts of four unsaturated fatty acids in the serum lipids of 14 patients who have undergone small bowel resection. The results are compared with those from 10 patients suffering from cancer of the oesophagus causing severe oesophageal obstruction and with 28 control subjects.

'Present address : Department of Surgery, Ichilov Hospital, Tel Aviv, Israel.

Received for publication 25 February 1974.

\section{Methods}

TOTAL SERUM LIPIDS

The lipids were extracted with 6 volumes of chloroform:methanol $(2: 1 \mathrm{v} / \mathrm{v})$ from $4-5 \mathrm{ml}$ serum. Insoluble protein was removed by centrifugation. The solvent was distilled off under reduced pressure in an atmosphere of nitrogen and the extract dried and weighed to estimate serum total lipid.

\section{FATTY ACIDS IN SERUM}

Methyl esters of free and esterified fatty acids were prepared with boron trifluoride (Jones and Hammond, 1961) and investigated on a Perkin Elmer F11 gas chromatograph with a dual flame ionization analyser. Separations were carried out on $2 \mathrm{~m}$ columns ( $2 \mathrm{~mm}$ id) packed with $20 \%$ diethylene glycol succinate on Chromosorb W HMDS (80100 mesh) using nitrogen $(40 \mathrm{ml} / \mathrm{min})$ as a carrier gas. All separations were carried out isothermally at $180^{\circ} \mathrm{C}$. Oleic, linoleic, linolenic, and arachidonic acids were identified by the use of pure standards (obtained from Sigma Chemical Co, St Louis, Mo). Eicosatrienoic acid was identified by comparison with fatty acids present in the liver lipid of rats fed on normal and fat-free diets; after three or four weeks on a fat-free diet, considerable amounts of eicosatrienoic acid appeared in the liver lipid, whereas it was undetectable in the liver lipid from the rat on a normal diet. The relative amounts of the unsaturated fatty acids were estimated from the peak areas, calculated by means of a disc integrator. 
Faecal fats were determined by Frazer's modification of the method of Kamer, Huinink, and Weyers (1949) as reported by Varley (1967).

\section{Subjects Studied}

All the subjects were Rhodesian Africans. There were 14 patients who had undergone resection of varying amounts of the small intestine. Resection was carried out for ileo-sigmoid volvulus in 11 patients, for adhesions in two others, and for intussusception in the remaining patient. The estimated amount of intestine remaining ranged from 416 to 148 inches. Lipid studies were carried out within five weeks of the operation.

The 10 patients with carcinoma of the oesophagus were investigated at the time of admission. All were malnourished as a result of virtually total dysphagia.

Eleven of the control subjects were patients admitted to hospital not suffering from gastrointestinal or nutritional disease. The remaining 17 were healthy medical students or laboratory technicians.

\section{Results}

TOTAL SERUM LIPIDS

The total serum lipid in the two groups of patients and in the controls is shown in table I. There was a slight elevation of the total serum lipid in the patients who had multiple resections of the small intestineand a reduction in those with carcinoma of the oesophagus.

UNSATURATED FATTY ACIDS IN SERUM Absolute values for the individual fatty acids in the serum lipids were not measured but relative

\begin{tabular}{lll}
\hline Subjects & $\begin{array}{l}\text { Number } \\
\text { of Subiects }\end{array}$ & $\begin{array}{l}\text { Serum Lipid } \\
(\mathrm{mg} \text { per } 100 \mathrm{ml})\end{array}$ \\
\hline Controls & 28 & $585( \pm 200)^{1}$ \\
Small-bowel resection & 14 & $659( \pm 163)$ \\
Cancer of oesophagus & 10 & $486( \pm 158)$ \\
\hline
\end{tabular}

Table I Total lipid in serum

${ }^{2}$ Figures in parentheses represent standard deviations.

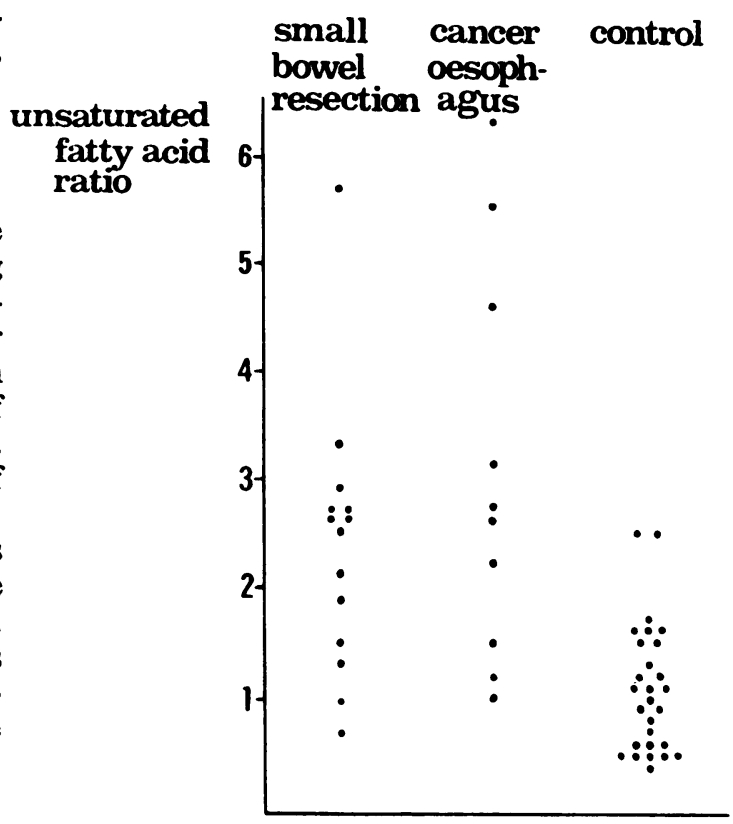

Fig Unsaturated fatty acid ratio:

$\frac{\text { Monoenoic }+ \text { trienoic }}{\text { dienoic }+ \text { tetraenoic }}$ in serum of patients who have

undergone small bowel resection and patients suffering

from cancer of the oesophagus compared with control subjects. Statistical analysis: Wilcoxon rank-sum test. Control values significantly lower than those of patients who had had a resection $(\mathrm{P}<0.02)$ and those with cancer of the oesophagus $(\mathrm{P}<0.05)$.

amounts of the saturated fatty acids are recorded as ratios in table II and the figure. Differences between the ratios were tested for significance by the Wilcoxon rank-sum test and it was found that both those obtained from small-bowel resection patients and those from cancer of the oesophagus patients are significantly higher than those from the controls $(\mathrm{P}<0.02, \mathrm{P}<0.05)$. The ratios of trienoic/tetraenoic acids from both groups of patients are higher than the normal ratio of 0.4 suggested by Holman (1960), results which suggest the development of

\begin{tabular}{|c|c|c|c|c|}
\hline \multirow[t]{3}{*}{ Subjects } & \multirow{3}{*}{$\begin{array}{l}\text { Number } \\
\text { of Subjects }\end{array}$} & \multicolumn{3}{|l|}{ Ratios } \\
\hline & & Trienoic & Trienoic & Monoenoic + Trienoic \\
\hline & & Tetraenoic & Dienoic + Tetraenoic & Dienoic + Tetraenoic \\
\hline $\begin{array}{l}\text { Controls } \\
\text { Small-bowel resection } \\
\text { Cancer of oesophagus }\end{array}$ & $\begin{array}{l}28 \\
14 \\
10\end{array}$ & $\begin{array}{l}0 \cdot 2(0-1 \cdot 6)^{1} \\
2 \cdot 1(1 \cdot 3-4 \cdot 0) \\
2 \cdot 2(0 \cdot 6-6 \cdot 0)\end{array}$ & $\begin{array}{l}0.05(0-0.3) \\
0.55(0.5-0.8) \\
0.45(0.2-1.1)\end{array}$ & $\begin{array}{l}1 \cdot 0(0 \cdot 6-1 \cdot 3) \\
2 \cdot 3(1 \cdot 5-2 \cdot 7) \\
2 \cdot 65(1 \cdot 2-5 \cdot 5)\end{array}$ \\
\hline
\end{tabular}

Table II Unsaturated fatty acids in serum lipids

'Values in parentheses represent $95 \%$ confidence limits. 


\begin{tabular}{|c|c|c|c|c|}
\hline \multirow[t]{3}{*}{ Patient No. } & \multicolumn{4}{|l|}{ Ratios } \\
\hline & \multirow{2}{*}{$\frac{\text { Trienoic }}{\text { Tetraenoic }}$} & \multirow{2}{*}{$\frac{\text { Trienoic }}{\text { Dienoic }+ \text { Tetraenoic }}$} & \multirow{2}{*}{$\frac{\text { Monoenoic }+ \text { Trienoic }}{\text { Dienoic }+ \text { Tetraenoic }}$} & \multirow{2}{*}{$\frac{\text { Faecal Fats }}{(g / p / 24 \mathrm{hr})}$} \\
\hline & & & & \\
\hline & \multirow{10}{*}{$\begin{array}{r}1.3 \\
2.4 \\
1.1 \\
0.0 \\
10.5 \\
0 \\
1.6 \\
2.4 \\
\text { Major Resection }\end{array}$} & \multicolumn{2}{|c|}{ Limited or Moderate Resection } & \\
\hline 1 & & 0.3 & $1 \cdot 3$ & 2.8 \\
\hline 2 & & 0.6 & 2.7 & - \\
\hline 3 & & 0.5 & $2 \cdot 6$ & - \\
\hline 4 & & 1.3 & $\mathbf{3 \cdot 3}$ & - \\
\hline 5 & & 0.6 & 1.9 & - \\
\hline 6 & & $\mathbf{0}$ & 0.7 & - \\
\hline 7 & & 0.5 & 1.5 & - \\
\hline 8 & & 0.5 & $2 \cdot 1$ & 24 \\
\hline 9 & & & & $10 \cdot 2$ \\
\hline 10 & 14 & 0.7 & 2.5 & 10 \\
\hline 11 & $3 \cdot 2$ & 0.9 & $\mathbf{2 \cdot 7}$ & 9 \\
\hline 12 & 0.0 & $4 \cdot 3$ & 5.7 & - \\
\hline 13 & 4.0 & 0.8 & 2.9 & - \\
\hline 14 & $1 \cdot 7$ & 0.5 & $2 \cdot 6$ & 41 \\
\hline
\end{tabular}

Table III Unsaturated fatty acids in serum of small-bowel resection patients and faecal fat excretion ${ }^{1}$

${ }^{1}$ The patients listed have been arranged in order according to the length of the small intestine resected. Case 1 had a limited resection of 16 in and Case 9 had $10 \mathrm{ft}$ of the distal small intestine removed. Cases 11-14 had only 70-74 in of residual small intestine.

essential fatty acid deficiency. Amounts of linoleic acid present in the serum samples were too small for measurement, therefore the trienoic acid shown consists of only 5, 8, 11-eicosatrienoic acid.

\section{RELATIONSHIP OF SERUM FATTY ACIDS TO} EXTENT OF INTESTINE RESECTION

Table III lists the unsaturated fatty acid ratios for the small bowel resection patients and indicates the extent of resection. Faecal fat determinations were available for only five patients and these are also given in table III; four of the five levels are somewhat high compared with normal values of 0.5 to $8.0 \mathrm{~g}$ per day suggested by Varley (1967). There appears to be no correlation between the extent of resection and fatty acid ratios.

SATURATED FATTY ACIDS

Although we were chiefly concerned with investigating relative changes in the unsaturated fatty acids, it was nevertheless possible to estimate the saturated palmitic and stearic acids approximately (as a percentage of total fatty acids) from the gas chromatographic data in some cases. The results obtained are

\begin{tabular}{llll}
\hline Subject & $\begin{array}{l}\text { Number of } \\
\text { Subjects }\end{array}$ & \multicolumn{2}{l}{ Percentage of Total Fatty Acids } \\
\cline { 2 - 4 } & & Palmitic & Stearic \\
\hline Controls & 15 & $23( \pm 4 \cdot 3)^{1}$ & $11( \pm 2 \cdot 5)$ \\
$\begin{array}{l}\text { Small-bowel } \\
\text { resection }\end{array}$ & 12 & $30( \pm 4 \cdot 2)$ & $12( \pm 2 \cdot 7)$ \\
$\begin{array}{l}\text { Cancer of } \\
\text { oesophagus }\end{array}$ & 10 & $26( \pm 5 \cdot 2)$ & $10( \pm 1 \cdot 2)$
\end{tabular}

Table IV Saturated fatty acids in serum lipids

'Figures in parentheses represent standard deviations. shown in table IV. There is little difference between the groups except in the case of palmitic acid, the percentage of which was slightly higher in the resection patients than in the controls $(P<0.0005$, Student $t$ test).

\section{Discussion}

The results reported in this paper demonstrate that the ratio of trienoic : tetraenoic acids in the serum of patients who had undergone small bowel resection is abnormal and suggestive of essential fatty acid deficiency (Holman, 1960). There was no obvious correlation between the results and the extent or site of the intestinal resection. A similar indication of essential fatty acid deficiency was obtained in patients with cancer of the oesophagus who were unable to eat and in these patients the total lipid serum was slightly lower than normal. In both groups of patients, the relative amounts of monoenoic and trienoic acids were increased and the dienoic and tetraenoic acids decreased.

Amongst the normal controls there were individuals who had ratios of unsaturated fatty acids indicative of essential fatty acid deficiency, so this is perhaps not so unusual on the traditional local maize diet. The difference between patients and controls is quite significant, however. Although it is not known what damage (if any) such a deficiency can do to man, these compounds have been shown to play a role in the maintenance of the integrity of cell membranes (Guarini and Johnson, 1970) which may affect both erythrocytes and mitochrondria. These results may indicate a case for supplementation of the low fat diet normally recommended with 
small amounts of unsaturated fat. Collins, Sinclair, Royle, Coats, Maynard, and Leonard (1971) found that supplementation of the diet with linoleic acid at a level of $2.2 \%$ of total calories was insufficient to reduce the triene/tetraene ratio in serum phospholipid below $0 \cdot 4$. However, this level did reduce the ratio to 0.6 but the patient was maintained at the time exclusively on parenteral nutrition. Supplementation at a level corresponding to the optimum requirement of $4 \%$ of calories by Adam, Hanser, and Wiese (1958) might be more appropriate. However, on an oral diet it is obvious that further experimentation would be desirable, in order to determine the optimum level of supplementation required to reduce the triene/tetraene ratio to the acceptable level.

We are most grateful to Dr S. H. W. Cmelik of the Department of Biochemistry for advice on the gas chromatographic techniques, and to Dr K. G. Gadd of the Public Health Laboratory, Salisbury, for the faecal fat determinations.

\section{References}

Adam, D. J. D., Hansen, A. E., and Wiese, H. F. (1958). Essential fatty acids in infant nutrition. II. Effect of linoleic acid on calorie intake. J. Nutr., 66, 555-564.

Collins, F. D., Sinclair, A. J., Royle, J. P., Coats, D. A., Maynard, A. T., and Leonard, R. F. (1971). Plasma lipids in human linoleic acid deficiency. Nutr. Metab., 13, 150-167.

Guarini, M., and Johnson, R. M. (1970). The essential fatty acids. Advanc. Lipid Res., 8, 115-174.

Hansen, A. E., and Wiese, H. F. (1954). Essential fatty acids and human nutrition. II. Serum level for unsaturated fatty acids in poorly nourished infants and children. $J$. Nutr., 52, 367-374.

Holman, R. T. (1960). The ratio of trienoic: tetraenoic acids in tissue lipids as a measure of essential fatty acid requirement. J. Nutr., 70, 405-410.

Jones, G. V., and Hammond, E. G. (1961). Analysis of the glyceride structure of cocoa butter by thermal gradient crystallization. J. Amer. Oil Chem., Soc., 38, 69-73.

Kamer, J. H. van der, Huinink, H. ten B., and Weyers, H. A. (1949). Rapid method for the determination of fat in feces. J. biol. Chem., 177, 347-355.

Varley, H. (1967). Practical Clinical Biochemistry, p. 424. Heinemann, London. 